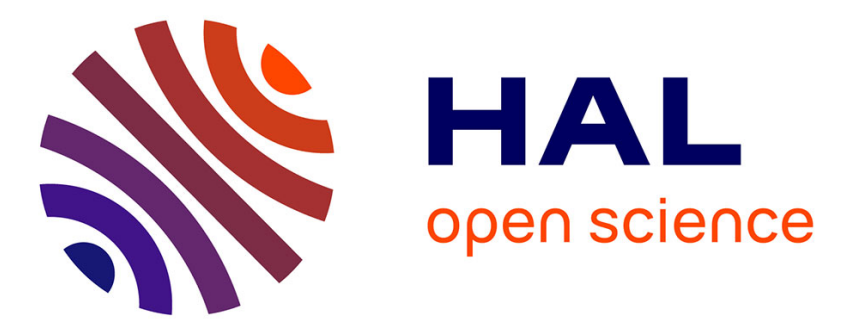

\title{
Cooperation in the shadow of regulatory competition: the case of asylum legislation in Europe
}

\author{
Ségolène Barbou Des Places, Bruno Deffains
}

\section{To cite this version:}

Ségolène Barbou Des Places, Bruno Deffains. Cooperation in the shadow of regulatory competition: the case of asylum legislation in Europe. International Review of Law and Economics, 2003, 23 (4), pp.345 - 364. 10.1016/j.irle.2003.07.001 . hal-01614082

\section{HAL Id: hal-01614082 \\ https://hal.science/hal-01614082}

Submitted on 10 Oct 2017

HAL is a multi-disciplinary open access archive for the deposit and dissemination of scientific research documents, whether they are published or not. The documents may come from teaching and research institutions in France or abroad, or from public or private research centers.
L'archive ouverte pluridisciplinaire HAL, est destinée au dépôt et à la diffusion de documents scientifiques de niveau recherche, publiés ou non, émanant des établissements d'enseignement et de recherche français ou étrangers, des laboratoires publics ou privés. 


\title{
COOPERATION IN THE SHADOW OF \\ REGULATORY COMPETITION : \\ THE CASE OF ASYLUM LEGISLATION IN EUROPE
}

\author{
Ségolène Barbou des Places ${ }^{1}$ and Bruno Deffains ${ }^{2}$
}

Classification JEL : K3

Keywords : asylum, refugees, regulatory competition, joint product, common pool

\begin{abstract}
It is the ambition of this paper to explain both the unevenness in the distribution of refugees in the European Union and the spiral of restrictions that have hardened the member states' asylum policies during the last fifteen years. Traditionally refugee and asylum legislation have been analysed in terms of public good. Nevertheless recent studies question this approach and emphasize the existence of private effects of asylum policies (security and altruism). They build upon a joint product model and advocate a decentralized asylum policy. This paper aims at complementing those studies and suggests that a common pool approach can best help to explain why EU national legislation has become restrictive from the mid-80's onwards. Indeed, in accordance with common pool models, the benefits of asylum policy are to be considered non excludable and rival. Therefore, when the number of protection seekers and the costs they represent reached a certain level, a process of inter-jurisdictional competition emerged among EU member states. States have started enacting convergent strategic regulations preventing asylum seekers from gaining access to their territories. But, as the paper shows, the set of procedures developed through competition has been excessively costly for states. A race to the bottom is observable that calls upon collective action at the centralized level.
\end{abstract}

\section{Introduction}

The question of refugee accomodation in Europe highlights differences in "burden" among EU member states. Geographic proximity to the region of crisis, the refugees' perception of the states' goals as well as ethnic or family ties produce situations in which some states attract

\footnotetext{
${ }^{1}$ Robert Schumann Center, European University Institute, Florence, Segolene.Barbou@iue.it

${ }^{2}$ CREDES, Université de Nancy 2, Bruno.Deffains@univ-nancy2.fr
} 
more refugees than others. Another factor that may explain these differences is legislation. Because the conditions for the reception of refugees and protection are not identical in all states, asylum seekers may choose their destination state on the basis of a preference for states providing better refugee treatment. Such a situation refers thus to so-called "asylum shopping" and prompts an examination of the evolution of legislation in European states from a comparative perspective. Two strategies can limit the asylum shopping phenomenon. According to the first, states with less developed protection systems may adjust their legislation to meet the standards of states granting refugees greater protection. The second strategy leads to an adjustment in the opposite direction, i.e. towards a minimum common denominator. During the 1990's the evolution of national policies in Europe has corresponded to the second scenario which has taken the form of a spiral of restrictions.

Indeed, from the mid-80's onwards, EU member states have introduced a wide range of procedures relating to the arrival, admission and entitlements of people wishing to claim refugee status on their territory. The terminology "procedure" used here encompasses all techniques, legal norms enacted by EU member states to control access to refugee protection. The States' main goal, as this paper will show, has turned out to be "to have as few refugees as possible". To this aim, states have first enacted procedures preventing asylum seekers from obtaining refugee status, mainly by impeding or by making extremely difficult the entry onto national territory. Visa requirements, the fining of airlines and shipping companies transporting undocumented people, reinforcement of borders controls, liaison officers posted in the countries of origin or transit have fuelled the idea of a "Fortress Europe" as much for refugees as they have for economic migrants. Secondly, states have modified the procedural guarantees for the asylum application examination in order to restrict them. Bureaucratic examination of the claim, untrained civil servants and arguable impartiality of the procedure have been noticed, as well as the practice of imposing on asylum seekers the obligation to prove/show that they have been persecuted or have a legitimate fear of persecution. Thirdly, observers have witnessed a growing tendency to interpret the criteria for refugee status in an increasingly restrictive manner. In other words, states have chosen a very narrow interpretation of the Geneva Convention definition of "refugee". The most significant example is the refusal to grant the status of refugee to people who are victims of persecution by non-state actors or fleeing civil wars. Fourthly, states have reduced the number of rights conferred upon asylum seekers who are already caught up in the asylum procedure, i.e. have lodged an application for asylum. As the UNHCR states (1997, p. 194), the effect was that of 
"discouraging them from pursuing their claim". Practices such as the withdrawal of social welfare and legal aid entitlements, the introduction of restrictions to the right to work and to education, and the protracted detention or imprisonment of asylum seekers, fall into this category. Lastly, all EU member states have developed measures encouraging the return or repatriation of refugees to their country of origin as soon as possible.

This situation is remindful of the regulatory competition argument that the globalisation of markets leads to downward pressures on regulation. The general idea is that mobile targets of regulation reduce their regulatory costs by moving to jurisdictions with low levels of regulation. Governments in turn ease off on regulation in order to attract larger shares of mobile factors and production processes with the result that regulation spirals down to ever lower levels. A well-known example of such a deregulatory spiral is the American experience with corporate chartering. In the US, corporate charters are granted by the individual states. Yet, since all states are required to recognize each others' charters, they have competed for incorporations by offering corporations friendly chartering requirements. In the course of this competition, the level of protection for shareholders, customers and the public has been progressively lowered : the result is described as a race to the bottom. Since Delaware won the race, the notion that regulatory competition develops a deregulatory dynamic has been dubbed the "Delaware effect".

Of course, refugees constitute a special kind of "transborder flow". Unlike capital, goods and services that also cross national borders, refugees raise the issue of social membership. Unless their stay is very short, they require some form of inclusion in the host society. Not only territorial boundaries, but national communities are also concerned and we have to take into consideration here the belief that membership involves costs. As will be demonstrated, the "Delaware effect" primarily takes root in the idea that states can avoid such costs by unilateral actions. During the 90's, this belief seems to have been at the origin of the governments' decision to restrict asylum rather than to enter into cooperative sharing schemes. As noted by Noll (1997), this dynamic corresponds to the classic Prisoner's Dilemna where two parties try to save themselves through unilateral action rather than accepting the costs which accompany the benefits of cooperation.

In this paper, it is our ambition to explain both the unevenness in the distribution of refugees distribution in the European Union and the spiral of restrictions during the last fifteen years. We adopt a law and economics perspective which stresses the consequences of legislative amendments on the choice of rational actors via their impact on the costs and 
benefits of decisions. Our purpose is to analyse the evolution of asylum legislation in Europe as the consequence of non cooperative behaviours. In this perspective, recent explanations refer to the well known problem of free riding in the provision of a pure public good. However, the common pool approach could provide a more adequate explanation of provision for refugees in the EU. To justify this proposition, first we must examine the nature of refugees provision. In part 2, we will show that granting asylum is not a pure public good. Part 3 is devoted to the analysis of regulatory competition. We propose to explain why it started, how it has developed, and what are its results. We use the common pool model in order to analyse the competitive process and will show that the procedures designed by states to manage flows of asylum seekers have been extremely costly. Part 4 demonstrates that spontaneous cooperation has been limited and inefficient. Burden sharing mechanisms have remained extremely limited, and attempts to foster cooperative behaviour in their current form are unlikely to achieve an optimal ratio costs and benefits. The paper concludes with the idea that centralized action is necessary. The communautarisation of asylum policy in 1997 with the treaty of Amsterdam should be developed.

\section{Provision for refugees as a public good ?}

\subsection{Benefits of making provision for refugees}

"Throughout the 20th century, and more specifically since the end of the second world war, states have devoted a considerable amount of effort and resources to the task of providing refugees with international protection. Their purpose has been twofold : first, to safeguard the lives and liberty of people whose basic rights have been threatened in their country of origin ; and second to safeguard their own interests by ensuring that large-scale population movements are managed in a predictable manner and in accordance with agreed principles". This presentation of the asylum legislation by the UNHCR (1997) can help to understand the goals of states which invest in provision for refugees. Such provision, whether it be in the form of directly granting asylum or voluntary contributions to refugee agencies, can be conceptualised as producing two kinds of benefits for states : security and altruistic benefits.

Security refers to the fact that once displaced beyond their national borders, refugees may constitute a potential threat to other states. According to Acharya and Dewitt (1995), security may be considered in this context as "the ability to control entry and exit so that the core values institutions and processes of that system are not threatened". Therefore, increased 
security can be regarded as the principal benefit of granting asylum, insofar as the accomodation of refugees potentially reduces the risk of refugees fuelling and spreading the very conflict from which they are fleeing.

But, security must be interpreted in a wider sense because the threats perceived by a host state relate not only to the recognition of refugee or asylum status but also to the resources required to effectively address those threats. As noted by Milner (2000), the burden cost created by the existence of refugees incorporates two components. Following Acharya and Dewitt, direct security burden refers to the threat of conflict spill-over within the vicinity of the country of origin. Indirect security burden concerns the impact of refugees on distributive justice and political opportunity within a given state that may be geographically more distant from the refugees' country of origin. More generally, we have to consider that refugees threaten governments and social harmony because they create serious financial and social burdens on the receiving nations. Indeed, refugee influx can increase competition for scarce resources such as employment, education and health care, and basic commodities such as housing. To be sure, the perception of security is related to the economic and social conditions in the host country. If the unemployment rate is low, states are more eager to receive skilled migrants. States with a high rate of unemployment, on the contrary, may be more immediately sensitive to the security threat in case of sudden and massive influx of asylum seekers. Massive flows of asylum seekers fuel the perception that exiled populations constitute a substantial threat to social stability and political security. Moreover, in political discourses, refugees are often associated with problems of crime, domestic violence, prostitution and drugs. Certainly, the perception of a threat to security is reinforced when the number of refugees increases in a substantial way. As will be shown, this effect is the determining factor in understanding why a regulatory competition process started from the mid-80s onwards.

Together with the security benefits resulting from the management of refugee movements, states can also expect altruistic benefits. Generally, altruistic externality appears when "the donor derives utility from knowing that less fortunate people are better off" (Sudgen, 1982). In the field of asylum, such benefits result mainly from the incidence of provision for refugees on the reputation of the country concerning human rights. As a matter of fact, "selling" the image of a state highly protective of human rights is one of the major private benefits that states can expect when developing generous asylum policies. Germany is a significant example: the right to asylum was incorporated into the constitution with the aim 
of limiting the executive power following the experience of the totalitarian Nazi state. Suhrke also explains Western countries' involvement in resettlement plans in the aftermath of the second world war as attempts to compensate the shame of second world war acts. It is no surprise then that Western countries, and particularly European states, have been strong advocates of the Geneva Convention on the Status of Refugees signed in 1951. This international convention, completed in 1967 by the New York Protocol, protects any person who, owing to a well-founded fear of persecution for reasons of race, religion, nationality, or membership of a particular group or political opinion, is outside the country of his nationality and is unable or, owing to such fear, is unwilling to avail himself of the protection of that country" (article 1). Up to now, European states have considered that Europe has a moral and historical responsibility to uphold the right to asylum. Therefore, national willingness to provide asylum is proof of commitment to respecting human rights. This explains that full compliance with international obligations remains of primary political importance on the international scene. This also sheds light on the instrumental use of the right to asylum granted to people fleeing persecution from communists countries before the fall of the Iron Curtain. Western countries have used their hospitality as leverage for the ideological struggle against communist states.

The different benefits of granting asylum give some interesting clues about the nature of the good under discussion. Considering that security and altruistic benefits are non excludable and non rival, the majority of specialists argue in favour of an international public good. According to Suhrke (1998), "if one state admitted refugees, the others would benefit from the greater international order that ensued regardless of their own admissions..., (so) refugees provision is an international public good from which all state benefits, irrespective of which country receives refugees".

The consequences of this interpretation of provision for refugees are important. According to public good theory, cooperation produces positive-sum benefits which in turn creates the will to share burden among actors as the benefits of the contribution exceed the costs of the contributors. At the international level, cooperation is thought to produce a level in the provision of a valued public good which individual states cannot attain on their own. In other words, public goods theory suggests that we should expect a significant under-provision of international public goods in the absence of central taxation and enforcement authorities. This problem exists because it is in the interest of an individual member to free ride on the efforts of others. Such arguments have been applied to the NATO context to explain not only 
the motives for cooperation on national defence but also to demonstrate that members of an alliance have an incentive to cheat by free riding on the common security provided by other members. The theory characterizes peacekeeping as providing a pure public good in the form of world security. The peace and stability achieved through peacekeeping activities produce non excludable and non rival benefits to all nations. It seems interesting to note that most studies adopt a similar vision for asylum because they consider that by improving the wellbeing of those in need, provision for refugees seems similarly to yield non excludable and non rival benefits for the community of nations. Generally, such characteristics give rise to free riding, by which states rely on the payments of others by withholding some or all of their estimated expenses.

Three important predictions derive from this approach :

- It can be anticipated that rich nations will shoulder a disproportionate burden of the public good for poor nations in terms of the share of the GDP allotted to provision for refugees. This disproportionate sharing of burden is known as "the exploitation hypothesis" (Olson and Zechauser, 1966). The economics of alliances suggests that in any burden sharing system, the distribution of costs and benefits will be skewed against the larger participants (Sandler and Hartley, 2001). According to Olson's argument, it is ceteris paribus the larger states whose action will make more of a difference to the total common effort than the action of small states. As a result, larger states will have an incentive to contribute a disproportionate share to the overall effort. We will therefore observe a systematic tendency for exploitation of the big by the small. In an effort to confirm this hypothesis, a number of studies have analysed the correlation of defence spending and GDP in the NATO context. They have shown that the United States, as NATO largest state, has contributed a disproportionate share of the burden for common defence.

- Public good reimbursements will be sub-optimal because a contributor will not account for the spill-over benefits that its contribution confers on others.

- Free riding and sub-optimization will worsen as the size of the group supporting the provision of the public good increases.

\subsection{From public good to joint product model.}

Although we have identified important predictions, the question still remains as to whether international provision for refugees constitutes a public good: in order to verify that claim we 
must turn to empirical evidence. The rare contributions on this subject that use the OlsonZeckhauser test suggest that the granting of asylum fails to conform to the pure public good model. For instance, if one puts the number of annual asylum applications in relation with the size of a member state's population or GDP, one finds that the top positions, i.e. the highest burdens, are predominantly taken by smaller states (Thielemann, 2002). Using a Spearman rank-correlation test, Betts (2002) sought to ascertain whether GDP is rank correlated with the level of burden borne. The principal idea here is that if there is a positive and significant correlation between GDP and Asylum provision as a proportion of GDP amongst the EU member states, there is "exploitation of the big by the small" such that EU asylum provision is an international public good ${ }^{3}$. The results are presented in the following tables.

\begin{tabular}{|c|c|c|}
\hline State & GDP rank $\left(R_{g}\right)$ 1993-98 & Asylum/GDP rank $\left(R_{\mathrm{a}}\right)$ 1993-98 \\
\hline Austria & 9 & 7 \\
\hline Belgium & 7 & 6 \\
\hline Denmark & 10 & 3 \\
\hline Finland & 11 & 9 \\
\hline France & 2 & 8 \\
\hline Germany & 1 & 4 \\
\hline Greece & 12 & 10 \\
\hline Ireland & 14 & 12 \\
\hline Italy & 4 & 14 \\
\hline Luxembourg & 15 & 15 \\
\hline Netherlands & 6 & 1 \\
\hline Portugal & 13 & 13 \\
\hline Spain & 5 & 11 \\
\hline Sweden & 8 & 2 \\
\hline United Kingdom & 3 & 5 \\
\hline
\end{tabular}

Table 1 : EU Member States'GDP $\left(\mathrm{R}_{\mathrm{g}}\right)$ and Asylum/GDP $\left(\mathrm{R}_{\mathrm{a}}\right)$ ranks for 1993-98

(average across 6 years) - Betts (2002)

\footnotetext{
${ }^{3}$ The author assumes that EU asylum is a normal good, for which the will to provide increases with GDP.
} 


\begin{tabular}{|l|l|l|}
\hline Year & $\mathbf{r}_{\mathbf{s}}$ & Critical value at the 0.05 level \\
\hline $\mathbf{1 9 9 3}$ & 0.30 & 0.441 \\
\hline $\mathbf{1 9 9 4}$ & 0.53 & 0.441 \\
\hline $\mathbf{1 9 9 5}$ & 0.42 & 0.411 \\
\hline $\mathbf{1 9 9 6}$ & 0.44 & 0.411 \\
\hline $\mathbf{1 9 9 7}$ & 0.38 & 0.411 \\
\hline $\mathbf{1 9 9 8}$ & 0.29 & 0.411 \\
\hline
\end{tabular}

Table 2 : Spearman Rank correlation between GDP and asylum burden ( $\mathrm{r}_{\mathrm{s}}$ given to 2 d.p.)

It appears that during the period 1993-1998, there is no empirical support for the exploitation hypothesis (at the 0,05 significance level). This statistical insignificance suggests that the level of free riding by poorer states on wealthier states is limited and that provision for refugees cannot be described as a pure public good : "the pure public good benefits fails to explain why some EU states unilaterally opt to provide disproportionately higher level of asylum provision than others despite being smaller in terms of GDP... Far from free riding, several economically smaller states such as the Netherlands and Denmark provide proportionally high levels of asylum, while some larger states, such as Italy and France, bear far less of the burden" (Betts, 2002, p. 9). How can such a situation be explained?

The principal explanation lies in the fact that asylum provision is more likely to yield some private benefits. As noted before, these benefits may arise from the enhancement of a State's status such as being recognized as a major promoter of human rights. Moreover, if a contributor is near the region of instability where the problem of accomodating refugees is most acute, then nation specific benefits may also stem from the reduced risk that the conflict will spread to them.

In this case, we have to refer to the "joint product" theory developed by Sandler and Hartley (2001) whereby activities are characterized as yielding both pure public good benefits for the community and contributor specific benefits. In the case of refugees, the collective action implications regarding the provision for refugees flowing from the joint-product model differ from those resulting from the pure public good scenario. More precisely disproportionate burden sharing needs not occur, so that burden cannot simply be correlated with an income measurement. If a poorer state receives a large amount of nation specific benefits, such as status enhancement, then it may carry a relatively heavy burden. Furthermore, sub-optimality will be attenuated as the share of nation specific benefits 
increases. If, for example, all derived benefits are nation specific, then an efficient allocation will be achieved since benefits match marginal costs. Additionally, increases in the size of the group supporting the good need not affect either free riding or sub-optimality if there is significant portion of state specific benefits associated with the good. It is important to note that the portion of the public ingredient found in joint products depends on the ratio of excludable benefits (i.e. state specific benefits) to the total benefits. As noted by Sandler and Hartley (2001), joint products may give rise to a coordination game in which one of the Nash equilibria has all players contributing to the collective action. If the portion of jointly produced private benefits is considerable enough with regard to the total outputs, then contributing to the defence activity may even become the dominant strategy. This has implications for the forming of alliances if alliance design allows potential allies to take advantage of ally specific benefits as well as excludable public benefits. Then, the payoff pattern may be more conducive to initial formation. Thus, by their very nature which is to combine private and public benefits, joint-products can influence alliance formation. For example, NATO burden sharing behaviour is generally considered optimal if nation specific benefits are integrated.

The joint product approach suggests that the amount of free riding in the provision of a particular good will be inversely related to the proportion of excludable outputs that the state produces. In other words, the more the country specific benefits gained from accommodating refugees, the fewer the opportunities to free ride. According to this model, we might therefore expect an inequitable distribution of refugees in the European Union as the private benefits differ from State to State. For example, the country "closest" to a particular conflict from which refugees emanate will have the greatest interest in stabilising the crisis through the accommodation of refugees (e.g. the case of Austria during the Balkans crisis). Moreover, there is substantive evidence for the claim that a country's willingness to host refugees is positively related to its more general commitment to norms such as human rights protection and solidarity (Thielemann, 2002). Certainly, differences in these norms generate divergences between states' benefits (and costs) evaluation, and therefore the provision for refugees. This is well illustrated by the evidence that it is the Scandinavian states and the Netherlands that provide disproportionately high levels in grants of asylum.

Finally, we deem that the heterogeneousness of provision for refugees among European states must be interpreted as the result of the difference in specific benefits rather than as a result of free riding. For a long time, the distribution of asylum seekers in the European Union 
was "inequitable", with a number of smaller states carrying a disproportionate share of the burden of welcoming refugees. But while the joint-product model may help to understand this phenomenon, it does not provide an analytical framework that is capable of explaining the substantial changes that took place in the 1990's: the unevenness in the distribution of refugees steadily increased and a spiral of restrictions appeared. We therefore propose to refer to the common pool problem and regulatory competition in order to explain this evolution.

\section{Competition in legal procedures and the common pool problem}

Following the logic inherent to the joint product model, we must refer to the costs and benefits of granting asylum for states. Two arguments may be put forward in order to explain a change in asylum policies. The first and usual explanation is that benefits have changed. After the fall of the Iron Curtain, altruistic benefits and reputation effects have been modified. Secondly, all EU member states have faced economic difficulties, recession and unemployment. Last of all, change in migration trends must be underscorred. Asylum seekers who were traditionally European and skilled migrants have been replaced by less skilled asylum seekers coming from other regions of the world, and thus are of different ethnic origins. A second and complementary explanation is that while benefits may not have substantially changed, the costs have grown with the number of refugees installed on the territory. The 90's witnessed the eruption of important conflicts that led to mass refugee movement, including refugee movement within Europe itself (ex Yugoslavia). The table below highlights this major change in asylum seeker trends and the massive increase of asylum seekers in Europe 


\begin{tabular}{|c|c|c|c|c|c|c|c|c|c|c|c|c|c|c|c|}
\hline & 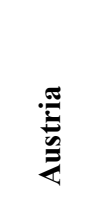 & 泀 & 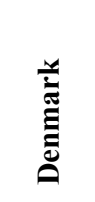 & 总 & 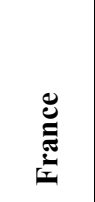 & 胥 & 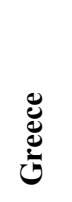 & 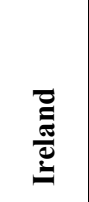 & $\frac{\lambda}{\underline{\Xi}}$ & 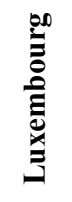 & 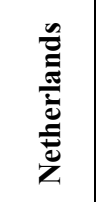 & 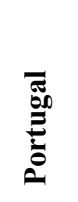 & 芯 & 总 & 总 \\
\hline 1980 & 9260 & 2730 & 70 & n.a. & 19910 & 107820 & 1790 & n.a. & 2130 & n.a. & 1350 & 1640 & n.a. & n.a. & 2350 \\
\hline 1981 & 34560 & 2290 & 120 & 20 & 19860 & 49390 & 2240 & n.a. & 3640 & n.a. & 1590 & 600 & 330 & 12650 & 2430 \\
\hline 1982 & 6310 & 2910 & 300 & 10 & 22510 & 37420 & 1190 & n.a. & 3140 & n.a. & 1210 & 1120 & 2460 & 10230 & 4220 \\
\hline 1983 & 5900 & 2910 & 800 & 20 & 22350 & 19740 & 450 & n.a. & 3040 & n.a. & 2020 & 610 & 1420 & 7050 & 4300 \\
\hline 1984 & 7210 & 3650 & 4310 & 30 & 21710 & 35280 & 760 & n.a. & 4560 & n.a. & 2600 & 380 & 1180 & 12000 & 2910 \\
\hline 1985 & 6720 & 5300 & 8700 & 20 & 28930 & 73830 & 1400 & n.a. & 5420 & n.a. & 5640 & 70 & 2360 & 14500 & 4390 \\
\hline 1986 & 8640 & 7640 & 9300 & 20 & 26290 & 99650 & 4230 & n.a. & 6480 & n.a. & 5870 & 280 & 2280 & 14600 & 4270 \\
\hline 1987 & 11410 & 5980 & 7590 & 50 & 27670 & 57380 & 6930 & n.a. & 11030 & n.a. & 13460 & 440 & 2480 & 18110 & 4260 \\
\hline 1988 & 15790 & 5080 & 11310 & 60 & 34350 & 103080 & 8420 & n.a. & 1240 & n.a. & 74902 & 330 & 4520 & 19600 & 4000 \\
\hline 1989 & 21880 & 8110 & 5280 & 180 & 61420 & 121320 & 3000 & n.a. & 2120 & n.a. & 13900 & 160 & 4080 & 30340 & 11640 \\
\hline 1990 & 22790 & 12960 & 18990 & 2740 & 54810 & 193060 & 6170 & n.a. & 4830 & n.a. & 21210 & 80 & 8650 & 29420 & 26210 \\
\hline 1991 & 27310 & 15170 & 12910 & 2130 & 47380 & 256110 & 2670 & 30 & 26470 & n.a. & 21620 & 260 & 8140 & 27350 & 44840 \\
\hline 1992 & 16240 & 17650 & 20070 & 3630 & 28870 & 438190 & 1850 & 40 & 6040 & n.a. & 20350 & 690 & 11710 & 84020 & 24610 \\
\hline 1993 & 4750 & 26880 & 16480 & 2020 & 27560 & 322610 & 810 & 90 & 1650 & n.a. & 35400 & 2090 & 12620 & 37580 & 22370 \\
\hline 1994 & 5080 & 14350 & 7990 & 840 & 25960 & 127210 & 1300 & 360 & 1790 & n.a & 52570 & 770 & 11990 & 18640 & 32830 \\
\hline 1995 & 5920 & 11420 & 10050 & 850 & 20170 & 127940 & 1310 & 420 & 1730 & 390 & 29260 & 450 & 5680 & 9050 & 43970 \\
\hline 1996 & 6990 & 12430 & 7390 & 710 & 17410 & 116370 & 1640 & 1180 & 680 & 260 & 22170 & 270 & 4730 & 5750 & 29640 \\
\hline 1997 & 6720 & 11790 & 5570 & 970 & 21400 & 104350 & 4380 & 3880 & 1860 & 430 & 34440 & 300 & 4980 & 9660 & 32500 \\
\hline 1998 & 13810 & 21970 & 6080 & 1270 & 22380 & 98640 & 2950 & 4630 & 11120 & 1710 & 45220 & 370 & 6650 & 12840 & 46020 \\
\hline 1999 & 20100 & 35780 & 6950 & 3110 & 30910 & 95110 & 1530 & 11090 & 33360 & 2910 & 39300 & 310 & 6410 & 11230 & 71150 \\
\hline 2000 & 18280 & 42690 & 10350 & 3170 & 38590 & 117650 & 3080 & 14800 & 14000 & 630 & 43900 & 200 & 7930 & 16300 & 75680 \\
\hline 2001 & 30135 & 24549 & 12403 & 1651 & 47263 & 88363 & 4650 & 10324 & 9620 & 689 & 32579 & 192 & 9219 & 23513 & 70995 \\
\hline
\end{tabular}

Table 3 : Asylum application in EU member states 1980-2001 (UNHCR, 2002)

The number of asylum applications in the European Union has increased six-fold from the early 1980 's to the early 1990 's. However, this increase has affected differently member states. From an EU total of 5,7 million asylum applications in the period 1980-2000, Germany 
took 2,7 million alone, Austria, Belgium, France, the Netherlands, Sweden and the United Kingdom accounted for another 2,5 million while the other eight member states dealt "only" with a million asylum applications. Our central concern is that the number of asylum applications has increased exponentially from the mid 1980s onwards. So, if we consider that every application for asylum implies financial, administrative and social costs, we submit that the opportunity cost for host countries became very high (and probably superior to perceived benefits) during the $1990 \mathrm{~s}^{4}$. Budgets of the government offices in charge of asylum procedures in France and Germany, for example, increased from FF 52,9 million in 1988 to FF 142,9 million in 1990, and from DM 143,5 million in 1992 to DM 486 million in 1993, respectively. According to Velling and Woydt (1993), the average annual cost of an asylum seeker in Germany was DM 12,000 to DM 15,000 at the beginning of the nineties, $50 \%$ of which may be accounted for by way of welfare benefits and $50 \%$ by way of the costs of accommodation and administration. If we add the social and political costs that states must bear when the number of refugees increases, the marginal cost of asylum policy is certainly growing. Refugees have an impact on distributive justice and political opportunity as well as create serious financial and social burdens on the EU states. As a consequence, this increase in the costs of asylum legislation has generated a change in behaviour, and the main European states have unilaterally implemented a number of deterrent measures. We propose to analyse this situation as a common pool game which triggers a negative regulatory competition.

For the purpose of simplification, let us consider that there is a fixed number of asylum seekers and that asylum seekers are costly for asylum countries ${ }^{5}$. In that case, there is a "good" for which EU member states compete, through the designing of asylum rules. The good in this particular case is "to have to care for as few refugees as possible". It is important to note that this good is both rival and non excludable. It is rival because lowering the number of asylum seekers in one country tends to increase their number in the other countries. And it is non excludable because no state can be excluded from attempting to admit fewer and fewer refugees. This only implies that each country is able to influence the number of asylum applications by changing its asylum policy. By becoming more restrictive a country deters future applicants. Consequently, the identified good is a common pool resource so that the

\footnotetext{
${ }^{4}$ Following Jandl (1995) and Betts (2002), we consider that the actual number of asylum seekers is a more accurate representation of the burden borne by a given state than any attempted estimates of expenditure levels that could be derived from available data.

${ }^{5}$ This proposition is not incompatible with the fact that immigration of workers in principle increases the welfare of economies, due to the greater availability of a production factor, thereby shifting the supply curve to the right.
} 
fundamental condition for regulatory competition is satisfied. The essence of the argument is that common pool resource creates individual incentives that leads to a sub-optimal outcome, or to a "tragedy" in Hardin's words. The dilemna can be captured by the following simple model in the field of asylum legislation.

\subsection{A two-jurisdictions game in deterrence}

Let us consider now the states which have the competence and the ability to deter asylum seekers by increasing the volume of administrative procedures, designated by $a$ (i.e. norms regulating access to the national territory, rules organizing access to legal protection and legal rights and subsidies conferred upon an asylum seeker once his/her refugee status is recognized). We assume that the greater the $a$ the higher the bureaucratic costs to manage the system of reception and protection of refugees. Restrictive and non liberal asylum policies imply costs related to border controls and strict asylum application examination. Note that a restrictive asylum policy is more costly than a liberal one. As a consequence, if a state prefers more $a$, it will be less attractive for asylum seekers but the costs per asylum seeker will be higher.

Let us suppose that asylum seekers have to find refuge in one of the competing states: when a country chooses $a$, it does not take into account the fact that its policy imposes costs on other states. In other words, an increase in $a$ imposes a negative external cost on the other states. The consequence is that each country will opt for a too restrictive asylum policy and supra-national coordination may appear necessary.

To demonstrate this phenomenon, imagine a world divided into two jurisdictions, 1 and 2. For reasons presented above, the jurisdictions spend resources on legal procedures in order to process asylum applications. Denote $a_{j} \in \mathrm{A}$ as the level of legal procedures chosen by jurisdiction $j$, where A denoting the set of possible legislations. Suppose that the welfare (of citizens) of jurisdictions 1 and 2 can be represented by $V_{1}\left(a_{1}, a_{2}\right)$ and $V_{2}\left(a_{1}, a_{2}\right)$, respectively. Thus, the level of procedures chosen by jurisdiction 2 has an impact on the welfare of jurisdiction 1 (and vice versa). Suppose further that $V_{j}\left(a_{j}, a_{k}\right)$ is strictly concave in 
$a_{j}$ and that $\partial V_{j} / \partial a_{k}<0, j \neq k$. Then, the latter inequalities implies, using the terminology of Eaton and Eswaran (1991), that the procedures of the jurisdictions are plain substitutes. The fact that procedures taking place in jurisdiction $k$ affects negatively the welfare of jurisdiction $j$ can be rationalized by the following argument : a more restrictive legislation in $k$ can "hurt" (in terms of indirect security burden) $j$ because refugees find it relatively more profitable to settle in $j$.

The problem of jurisdiction 1 is $\max _{a_{1}} V_{1}\left(a_{1}, a_{2}\right)$. The first - and second-order conditions of this maximization problem are, respectively, $\partial V_{1}\left(a_{1}, a_{2}\right) / \partial a_{1}=0$ and $\partial^{2} V_{1}\left(a_{1}, a_{2}\right) / \partial^{2} a_{1}<0$. This defines a reaction function for jurisdiction $1: a_{1}=f_{1}\left(a_{2}\right)$. For jurisdiction 2 , the analogue to the problem of jurisdiction 1 leads to a reaction function $a_{2}=f_{2}\left(a_{1}\right)$. A Nash equilibrium is then a pair $\left(a_{1}^{N}, a_{2}^{N}\right)$ such that $a_{1}^{N}=f_{1}\left(a_{2}^{N}\right)$ and $a_{2}^{N}=f_{2}\left(a_{1}^{N}\right)$. This is depicted in figure 1 in the $\left(a_{1}, a_{2}\right)$ space. The case where the reaction curves are negatively sloped is represented here. The Nash Equilibrium pair $\left(a_{1}^{N}, a_{2}^{N}\right)$ lies at the intersection of the two reaction curves and is denoted $N$.

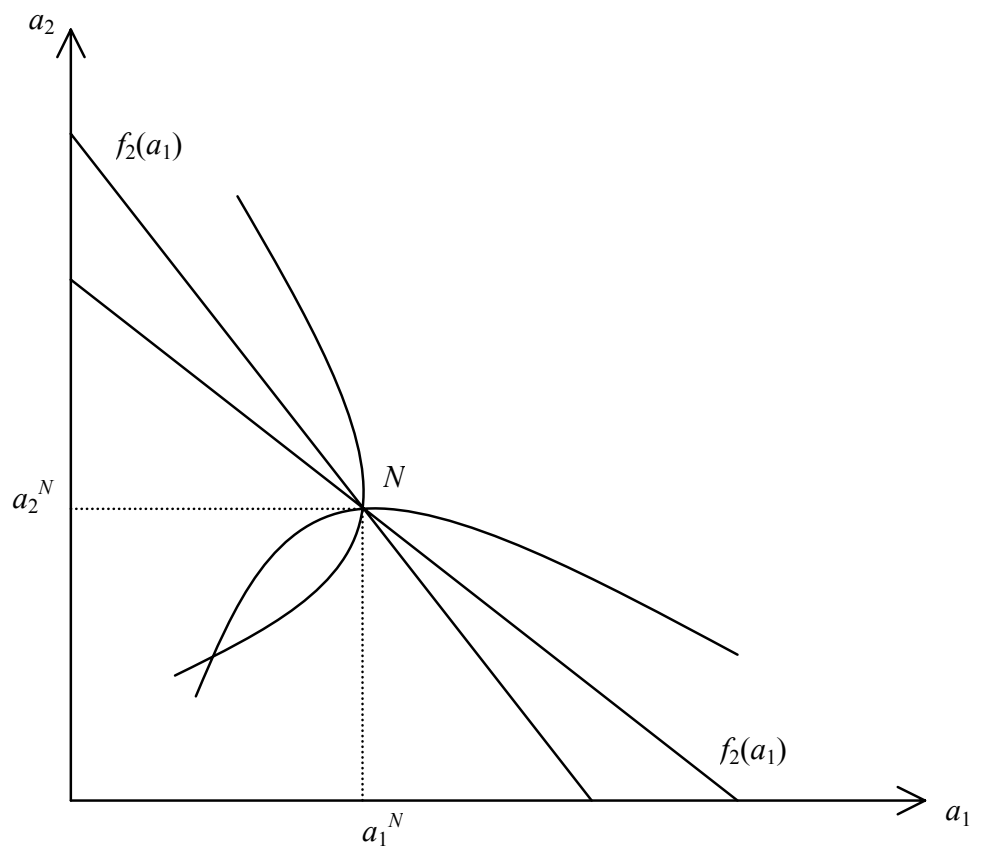

Figure 1 : Nash equilibrium

It has been shown by Eaton and Eswaran (1991) that in the case where the actions of the players are plain substitutes, the Nash equilibrium level of the actions is higher than the 
Pareto efficient (efficiency) level. In the context of the present analysis, this means that the Nash equilibrium level of legal procedures is higher than the Pareto efficient one. In other words, too many constraints are placed on the jurisdictions. This can be seen in figure 1, where the jurisdictions' indifference curves through the Nash equilibrium are depicted (denoted $u_{1}$ and $u_{2}$, respectively). Note that because procedures are plain substitute, an indifference curve for jurisdiction 1 (2) is necessarily concave to the horizontal (vertical) axis. It is possible to see that all the points in the hatched area at the southwest of $\mathrm{N}$ (where) would improve the situations of both jurisdictions. Hence, the Nash equilibrium is not Pareto efficient : it entails legislation that is too restrictive. Note that this result holds whether the procedures of the jurisdictions are strategic substitutes or strategic complements.

The intuition behind the too restrictive legislation result is that a jurisdiction, when choosing its level of procedures, trades off its own benefits (reduced number of refugees and increased indirect security) and costs (forgone resources, perhaps reduced direct security), but does not take into account the fact that this has a negative impact on the welfare of the other jurisdiction. In other words, there are costs to other jurisdictions that are not internalised. Finally, according to the model, the jurisdictions, in the absence of regulation (or collective action) earns less than what they potentially could if the resource was properly managed.

\subsection{Evidence of regulatory competition}

We propose now to give empirical evidence of regulatory competition among EU member states' asylum legislation. First, we will show that competition has emerged as the consequence of asylum shopping. Considering the costs of accomodating refugees for member states and the increasing and uncontrolled mass influx of protection seekers, states have engaged in a competitive process so as to avoid becoming overburdened. Thereby we will explain how states have been responsive to asylum seekers' preferences and have adapted their legislation by enacting strategic externalisation measures.

The regulatory competition process did not start per se. Rather it was triggered by real or feared asylum shopping. Statistical data provided by UNHCR points to the conclusion that during the 80's and the 90's, asylum seekers modified their choice as a consequence of restrictive amendments to asylum law. For instance, the German constitution was modified restrictively in 1993. The following year, the number of asylum applications decreased from 438190 to 127 211. In Spain, the major restrictive amendment occurred in 1994. Before 
Spain abandoned its liberal legislation, the number of asylum applications was on the increase every year (8140 in 1991, 12620 in 1993). But in 1995, the number of asylum applications dropped to 5680 applications. The same evidence can be given for France (years 1991-1992), Sweden (years 1992, 1993), the Netherlands (1994-1995) i.e. there is a correlation between restrictive legislation year $t$ and the substantial decrease in asylum applications year $t+1$.

These data are evidence of an economic actor's responsiveness to differences in legal actions. A priori comparable responsiveness seems unlikely with regards to asylum seekers who, after all, are people trying to save their lives, or at least their physical integrity, a fact that casts doubt on their capacity to compare rules and select the country or destination on the basis of better treatment to be expected in one country or another. But, first of all, UNHCR and sociological studies (Chatelard, 2002) show that asylum seekers have access to information (directly or by the channel of smuggling networks). Secondly, while in other fields such as social law (Barnard, 2000) or company law (Deakin, 2000) regulatory competition among EU member states is arguable, we hold that mobility and the capacity to vote with one's feet is more than plausible for asylum seekers. Indeed many factors impede companies' mobility (legal rules such as the criterion of real registered office, costs of reincorporation, limited knowledge of each jurisdiction's revenue and expenditure patterns). On the contrary obstacles to mobility must be extremely high indeed (border sealing) to prevent people from crossing over borders. The high costs of mobility are of no significance to people fleeing persecution. Moreover, the condition regarding knowledge of each jurisdiction's revenue and expenditure patterns is easier to meet in the case of asylum. While reincorporation is a very complex decision for a company that requires taking into account a vast quantity of elements, the choice of a destination state is based on rather simple criteria for asylum seekers (right to enter, to residency, access to employment and social protection).

If this description is debatable it is on other grounds. Studies indicate a multiplicity of pull and push factors for asylum seekers choosing their destination state. (Bocker and Havinga, 1998). Legal rights to be expected are only one among many criteria that trigger the decision. Rotte, Vogler and Zimmermann (1996) confirm the importance of other elements in the choice of the destination state but show that legal norms have a major influence on the decision. They analyse different variables that may constitute pull factors to a destination country and conclude that change in law influences significantly asylum migration. Be that as it may, not all the migrants modify their choice and are redirected after a state modifies restrictively and significantly its legislation. The reality of the arbitrage among legal norms 
might be a weaker factor than expected. But pressure on law suppliers has clearly taken the form of fear of an eventual arbitrage (Barbou des Places, 2002b). Analyses of public opinion, together with political declarations give evidence of the fear of an invasion of refugees if the national asylum provisions are too welcoming. Even in countries which have comparatively strict legislation, general public opinion may esteem that controls are too lax and may even be persuaded that their State is carrying all the burden of refugees in Europe. Current efforts to harmonise refugee law provisions are generally justified by the desire to eliminate the differences in levels of protection among legislation that feed asylum shopping : states now publicly voice their concern that favourable conditions in one country might create an 'indraught' (Bouteiller-Paquet, p. 176). Just as the prospect of lucrative re-incorporation encouraged the American states to ease up on their chartering standards, the 'Delaware effect' can be observed in the case of national asylum policies. The real or perceived threat of huge flows of migrants entering their territories gives member States an incentive to adapt their legislation following the example of their direct competitors.

Consequently, if asylum shopping creates incentives for states to take the legislation of their neighbours into consideration, we have to assess the degree of legal interdependence. We are not hypothesizing perfect competition but the process of regulatory competition in its dynamic sense, as rivalry among legislators (Deffains, 2001). Observing law suppliers' actions, we want to make evident the states' reaction function as defined in point 3.1. Taking the example of France and Germany, Rotte, Vogler and Zimmermann (1996) first took a closer look at national measures in legal terms for asylum migration and their actual effects on the partner countries. The basic idea is to find empirical evidence for existing interdependence between asylum migration to France and Germany, respectively, which may be influenced by legal actions. They estimated two ordinary fixed-effects panel models, the number of asylum seekers for each country being the endogenous variable. The vector of exogenous variables included several indicators for socio-economic and political positions. Potential spill-over caused by national legislation were modelled by including legal procedures of a country in the equation for the other one. As noted by the authors, "the most important finding is that the French law reforms in 1991 resulted in an increase of asylum seekers coming to Germany instead". Despite its isolated nature, the study showed that there is considerable interdependence of asylum policies in the EU. This means that national legislation aimed at a further reduction in asylum migration contains a potential for "devaluation races" in asylum laws among member states using beggar-my-neighbour effect in this field. 
Together with the amendment of the provisions organising the access to refugee status, states have created new legal statuses for asylum seekers. These new statuses, whether they are referred to as humanitarian, territorial asylum, or de facto promoted by the UNHCR, confer legal protection to persons falling outside the scope of the Geneva convention and thus unable to have access to the refugee status. They permit accomodation of persons fleeing civil wars or of victims of persecution by non state actors (Duldung in Germany, F status in Denmark, exceptional leave to remain in the UK,...). At first glance, the implementation of these new statuses is proof of generosity : states have accepted to receive and protect additional categories of people. But in reality, states have complete autonomy to grant these statuses: they are not bound by the principles of the Geneva Convention and the statuses provide only a very temporary protection. Therefore, a more acute analysis leads on to the conclusion that states have accepted to create new forms of protection, statuses, in order to internalise and control the protection granted as well as to avoid some constraints of the Geneva Convention (less rights are conferred on protected persons).

The combination of restrictive amendment of the legal norms implementing the Geneva Convention obligations and the creation of new and less costly statuses must be interpreted as European legislators' response to asylum shopping. Indeed, unilaterally, each state has tried to develop mechanisms that aim at dissuading asylum seekers from selecting it as the future host country. The purpose of the new norms was also to redirect the flows of asylum seekers to their neighbours. In fact, competition has taken the form of deliberate use of national regulations as a strategic weapon in international competition in which gains in one country are at the expense of costs imposed on others. The simultaneity of law amendment together with convergence of the content of the procedures established during the 80 's and 90's are evidence of a "beggar-thy-neighbour" attitude and a race to externalise.

Three sets of techniques, invented in one country and then copied by the others, are particularly significant. The first took the form of sanctions imposed on carriers transporting improperly documented passengers. Initially conceived of by Danish law in 1983, the measure has since been introduced in its national legal order by Germany, the UK and Belgium in 1987 and then imported into the Schengen Convention in 1990. Logically then all other member states have copied the technique that decentralizes and privatises border controls (Cruz, 1995). The second example concerns the creation of international or transit zones in ports and airports. The goal is to avoid the official entry onto national soil that triggers a State's responsibility towards the asylum seeker. France introduced the system in 
1992. Then Italy, a few months later, Germany in 1993, and Spain in 1994 all copied the technique, rapidly followed by the majority of the member states. A third convergent evolution in member states' legislation was its incorporation of two complementary concepts: "safe third country" and "manifestly unfounded application". A person coming from a safe third country will not have access to the status of refugee and will generally be refused the right of entry onto the national territory. The concept of manifestly unfounded application justifies the curtailing of the examination procedure, limits procedural rights and guarantees and can result in a complete refusal to grant refugee status. All member states have enacted provisions enhancing the two techniques.

Convergence is noticeable with regards to legislative content, as predicted by the theory of inter-jurisdictional competition. In practice, the effects of the preceding measures are to directly repel asylum seekers and redirect then towards other countries. Member states have designed diversion policies, also described as "market deflection" (Noll, 2000) or as "containment strategy". The result is empirically observable : when one member state implements a measure that, for instance, institutes carriers' liability or defines safe third country, one or several other member states then become the receptacle for the asylum seekers who have changed their destination. Therefrom the chain amendments that proves the interdependence of national asylum legislation (Rotte, Vogler and Zimmerman, 1996) and the strategic use of norms as leverage for competition.

Last of all, in the wake of the German system, states have developed measures deflecting asylum seekers towards non European states. Thanks to the signature of readmission agreements with Central and Eastern Europe, liaison officers posted at the main airports in countries of transit or origin, member states have progressively developed the socalled "buffer zone" that prevents asylum seekers from approaching European borders. One may argue that these externalisation policies are not related to competition among member states. In reality, it is part of the competitive process. The first states to make readmission agreements gained a 'first mover' advantage. One can observe that each efficient technique invented by one state is likely to quickly spread throughout Europe to the others via a copy and pasting phenomenon. 


\subsection{Evaluation of competition : "devaluation races"}

All legal scholars have dwelt on the constant and convergent restriction of legal rights conferred upon asylum seekers in the EU member states. They have described a "new asylum regime" that reflects the paradigm of the change over from a regime implementing a selective but integrative policy of access and full status recognition paired with full social rights, to one which maximises exclusion, undermines status and rights and emphasises short-term stay for refugees (Joly, 1999). This description seems to indicate the existence of a race to the bottom.

First of all the actions developed by member States have jeopardised the security of potential and actual asylum seekers. The measures impeding access to territory have obstructed the flight of people who have a genuine fear of persecution in their country of origin: they are unable or unlikely to obtain refuge in a neighbouring state. Moreover, through the use of the concepts of safe third country and manifestly unfounded application measures, asylum seekers are bounced back and forth between countries until one finally accepts to play host to them. The chain deportation phenomenon that is a result of these practices ultimately adds to the psychological and physical trauma already experienced by asylum seekers. Lengthy procedures are also problematic because before their asylum application is fully examined and a status granted or refused, asylum seekers are left in a legal limbo, sometimes without subsidies. This situation creates difficulties for asylum seekers but it is also a source of problems for the host state, and a particularly significant one because asylum procedures take an average of three years.

Second of all, in comparing states' goal (to get as few refugees as possible) with the instruments used to achieve it (restrictive procedures), one discovers that the result is suboptimal. Experience to date shows that although the array of restrictive measures may have slowed the inflow of asylum seekers, it has certainly failed to stop it. Moreover, "in attempting to limit the number of asylum seekers arriving and remaining on their territory, these states have actually damaged their own interests" (UNHCR, 1997, p. 196). Indeed, as noted before, the costs of bureaucracy have proven to be considerable and it seems possible to argue that states, by putting the accent on migration control and border protection, have spent a very high quantity of human resources (custom, police, civil servants in charge of asylum application examination). The systems developed to reduce costs have in fact generated new costs. The chain deportation system has required the use of new resources contrary to the original intention of the countries (ECRE, 1995, p.7). In addition, during the competitive process, states have amended their legislation very frequently, sometimes every year. We 
must underline the costs of modifying legislation (costs of legislative procedure, time spent by members of parliament and civil servants involved, costs of implementation of the new law etc). These costs are even more significant when it is the fundamental law that is amended.

A third and problematic aspect of regulatory competition is compliance of certain legislation with international obligations. All member states are bound by the provisions of the Geneva Convention, the New York Protocol and the European Convention of Human Rights as interpreted by the European Court of Human Rights. In order to redirect asylum seekers towards other countries, states have enacted measures which are arguably in full conformity with international norms. The use of concepts such as safe third country and manifestly unfounded application has been criticised. UNHCR has stressed the fact that the examination of manifestly unfounded application is made too quickly, without any guarantees (HCR, comité exécutif, conclusion $n^{\circ}$ 30/XXXIV sur le statut des refugiés et le problème des demandes manifestement infondées et abusives). Moreover, these concepts correspond to a minimalist interpretation of the Geneva Convention. Many scholars consider that it contradicts a general principle governing the interpretation of texts concerning rights and freedom: the nature of the rights garanteed by these texts demand an open, generous and teleological interpretation that favours the greatest protection possible of the dignity of the victims (Crepeau, 1995). The creation of transit and international zones is another worrying example. No international norm permits these zones to be considered as non territorial spaces where the rule of law would not be implemented. Lastly, doubts have been raised on the compatibility of the carriers' liability norms with both the 1944 Chicago Convention on International Aviation and the Geneva Convention insofar as article 31 of the latter, forbids the imposition of any sanction on persons seeking asylum and entering the country of refuge undocumented.

These potential encroachments upon the spirit of the international provisions are costly for states' international reputation. Part of their international image and benefits gained from hosting refugees is to be able to tout themselves as protectors of human rights. Logically, states now face problems of legitimacy in certain arenas. UNHCR $(1997$, p. 69) notices that when the very same countries responsible for establishing the international refugee regime begin to challenge its legal and ethical foundations, then, unsurprisingly, other states, especially those with far more economic problems and much larger refugee populations, have decided to follow suit. Increasingly, when low-income countries close their borders to refugees, they tend to justify their actions by referring to the precedents set by the more 
affluent states. The degradation of the protection of refugees in Third World countries has an impact on member states' asylum policies. When transit countries, frequently overburdened, refuse to sign or ratify the Geneva Convention or grant limited protection to refugees, European countries cannot consider them as "safe" and therefore cannot make use of the safe third country technique. Ultimately the efficiency of their deflecting measures is challenged by their very own policy.

In addition, the settings of containment measures can be challenged before national courts when the measures enacted are in contradiction with national norms (e.g. the constitutional right to asylum). In December 1996, in its decision Ministre de l'Interieur c/ Rogers, the French Conseil d'Etat refused to consider as manifestly unfounded Mr Rogers' asylum application on the simple ground that, before entering French national territory, he had transited through a state signatory of the Geneva Convention ${ }^{6}$. The French legislator has taken this case into consideration: by the Law 98-348 of May $11^{\text {th }}, 1998$, the Parliament has repealed the "safe third country" notion from French legal order. The French Conseil Constitutionnel in its Decision of February $25^{\text {th }}, 1992$, limited the possibility to set up transit zones. Numerous other examples of case-law could be given that critically address restrictive measures. They all indicate that states are likely to face internal criticism from their own constituencies, and even outside the NGO fora related to the protection of refugees.

Finally, the procedures set out by EU member states have created side effects. The accent must be put on the growing rate of human trafficking that results from restrictive procedures. Following UNHCR (1997, p. 199), there is now a consensus that "the restrictive asylum practices introduced by many of the industrialised states have converted what was a relatively visible and quantifiable flow of asylum seekers into a covert movement of irregular migrant that is even more difficult for states to count and control". There is also widespread agreement that such irregular movements are increasingly organised by professional traffickers. Chatelard (2002) showed that, in the case of Iraqis, the fact of keeping asylum seekers out has had the side effect of allowing for the development of networks of migrant smugglers (See also Salt and Hogarth, 2000 ; Ghosh, 1998). Accordingly, to avoid being returned to the safe third countries by which they have transited, many asylum seekers destroy their identity documents and passeports or cheat when they describe their migration route. The restrictive measures have thus driven migration underground. As a result, states are forever obliged to reinforce procedures and to allocate more human resources in order to fight

\footnotetext{
${ }^{6}$ CE, Ass., 18 decembre 1996, ministre de l'interieur c/ M. Rogers, n 180856, conclusions M. Delarue
} 
against smuggling networks, abuses of their asylum systems, which constitute significant indirect costs of bureaucracy.

\section{Initiating the European cooperation}

The previous lines have focused on states' unilateral actions at the origin of the common pool problem. But the game is not static and institutional solutions generally emerge to solve the collective action problem. The principal way refers to spontaneous cooperation. For example, when the interaction among the users of a CPR is indefinitely repeated, the outcome does not have to be a tragedy but might indeed be optimal (general feasibility theorem or folk theorem). When transaction costs are low, such self-emerging institutions imply community building, information gathering or sanctioning devices. In practice, one can observe that these different institutional forms of cooperation exist in the asylum legislation in Europe but there are many obstacles to impose definitively cooperation between member states. This situation contributes to explain the increasing role of the European authority in this field.

\subsection{The obstacles to spontaneous cooperation}

The early 90's saw important attempts to organise cooperation schemes among member states. Numerous norms enacted at that time show evidence of a spontaneous and decentralised cooperation. They reflect a common will to achieve two entangled goals : limit the asylum shopping phenomenon that generates regulatory competition and substitute burden sharing mechanisms (i.e. collective action) for unilateral strategic behaviours.

The Schengen Implementation Convention (SIC) and the Dublin Convention determining the state responsible for examining applications for asylum lodged in one member state of the European Communities (entered into force in September 1997) were the first moves towards limiting the competitive process. The goal of the SIC and Dublin Convention was to set up mechanisms which would transform the asylum seekers' opportunity to choose his/her destination country into a legal state-oriented determination. To this aim, the Dublin Convention has laid down six criteria that determine which contracting party is held responsible for processing the asylum application, thereby preventing the asylum shopping that results from the initiation of parallel or successive applications in several member states. The six criteria, hierarchically ordered are as follows : family-ties criterion ; the issuing of a residence permit; the possession of a valid visa ; illegal entry; the permission 
to enter without a visa ; first time application for asylum. The main characteristic of the system is that the criterion in relation to individual choice of a responsible country appears at the very bottom of the list. Thus, the opportuneness of forum shopping tends to be absorbed by state-based control (primacy of criteria stressing state action like issuing a visa, a residence permit etc). In terms of regulatory competition, member states have collectively tried to restrict the mobility which allowed for arbitrage and then competition. Secondly, the system imposes on member states the internalisation of generous or lax asylum and migration policies.

During the same period, member states started negotiating and discussing burden sharing mechanisms. In 1992, a Common position referred to burden sharing in order to ensure a just and lasting solution for people fleeing the Yugoslavian war. In September 1995, the Council adopted a resolution on the distribution of responsibility among member states, (OJ 1995, C262/1/3, 7/10/1995). In 1996, a Decision was enacted laying down an alert and emergency procedure on burden sharing with regard to the admission and residence of displaced persons on a temporary basis (Council Decision of 4 March 1996, OJ L63/10, 13 March 1996). These norms have been pushed by active and overburdened states mainly Germany and Sweden. From the early 90's onwards, these two countries have constantly proposed and promoted burden sharing schemes (Swedish proposal on burden sharing in November 1993; German draft Council Resolution on burden sharing with regard to the admission and residence of refugees of July 1994). This action in favour of burden-sharing must not be understood as a strategy supported by over-burdened states in order to rid themselves of an excessively large number of protection seekers. It should be viewed, instead, as a means to maintain and restore the states' admission capacity in the long term (Hailbronner, 2000). As a matter of fact, burden sharing plans in the field of asylum are praised because they express an ethical asylum policy (Harvey, 1998), based on solidarity and equality among states belonging to an ever closer Union. They are analysed as insurance mechanisms (Suhrke, 1998), helping states to increase or maintain the protection granted to asylum seekers, avoid peak costs (Noll, 2000) and ensure greater fairness to asylum seekers.

The apparent change in logic that appeared in political debates must now be confronted with reality and results. Can we assess efficient cooperation, i.e. what are the results of these complementary mechanisms set out by states ? 
Keeping in mind the negative results of regulatory competition stated above, one may indicate that, to a certain extent, cooperative schemes have permitted states to reduce the costs of their restrictive asylum policies. For instance, Crepeau (1995) considers that the Schengen and Dublin conventions, mechanisms of sharing responsibility, can allow states to use efficiently their scarce resources on applicants presenting greater needs of protection and avoiding in orbit-refugee (i.e. asylum seekers whose asylum applications are never examined). Be that as it may, the major interest of cooperation is that " member states have benefited from acting collectively to achieve migration-related objectives, such as restrictive entry, without ceding their authority to Community competence" (Thouez, 2000 p. 1). In other words, one may argue that states have used common norms to legitimate at the internal level the shift towards restrictive asylum legislation. Indeed, the Dublin Convention allows states to send back an asylum seeker to a third country even when the criteria indicate that one of them is responsible for processing the case. In 1992, a resolution was adopted in London (resolution on a harmonised approach to questions concerning host countries). It indicates that the possibility of rejecting an applicant to send him/her to a third country outside the European union should be considered before ascertaining whether a member state or another might be responsible on the basis of the Dublin Convention. Using the two-level games metaphor, Vink concludes that governments have pursued restrictive policies that are perhaps not very different from those that they would have pursued in the absence of European cooperation. But they could get away with it more easily by strategically profiting from the European playing field, especially the frontrunners, countries such as the Netherlands or Germany, who can then try to shift the blame to Europe for the hardening of their asylum policies. (Vink, 2001). Collective action is a powerful justification indeed of restrictive policies.

In terms of costs and benefits, (mainly costs induced by the loss of a good reputation and tensions with constituencies), collective action is slightly positive. States have chosen international cooperation precisely because the balance of forces was in their favour. By acting at the international level, states have managed to avoid certain national judicial constraints and have got around opposition from parliamentarians and NGO's supporting migrants (Guiraudon, 2000)

Yet, cooperation attempts have failed to provide the expected results. The Dublin Convention has not suppressed asylum shopping and faces fierce criticism. Lengthy procedures, unclear criteria, the fact that few asylum seekers are ultimately transferred from 
one country to another, longer periods of uncertainty, incentives to destroy identity and travel documents, incitement to prefer illegality over transfer to a country which is not seen as a feasible option appear to be problems endemic to the system. This points to the fact that cooperation has not reduced the costs of asylum for states. On the contrary, the implementation of the Dublin system of responsibility allocation and transfer of asylum seekers has increased human and technical resources requirements. Moreover, indirect costs of clandestinity have increased since asylum seekers prefer to disappear rather than accept being transferred from one country to another. They also prefer to withdraw their asylum applications to avoid the transfer and remain in illegal situation. Last and mainly, asylum seekers have developed strategies to keep on choosing their destination state. Informed of the Dublin criteria (especially the fourth, i.e. illegal entry), some protection seekers avoid the official procedure of visa or residence permits requirement and instead choose illegal entry into their preferred destination state. In reality, none of the cooperation instruments has seriously limited the arbitrage and asylum shopping has not decreased.

Concerning the burden sharing aim, the results are not positive either. The 1995 resolution and the 1996 decision have not created any common rule concerning uniform admission, return, or rights granted to displaced persons. The early 1990 proposals were ambitious and proposed systems of responsibility sharing (people sharing) i.e. mandatory distribution of asylum seekers among member states. The German draft of 1994 was farreaching as it advocated distribution of protection seekers among member states according to a distributive key based on member states' percentage of the total Union population, percentage of the Union's territory and percentage of the Gross Domestic Product of the Union. But strong reservations from France and the UK watered down the project. In the end, as a result of this opposition, only a light system was adopted by the 1995 decision on alert and emergency procedure that abandoned the system of allocation of people.

Logically, the unevenness in the burden borne by member states did not diminish during the 90's. All data confirm the disparities in the distribution of protection seekers in Europe, both for refugees and for temporary protection seekers during the Yugoslav crisis (UNHCR, 1999). Moreover the Dublin mechanism has created concentration effects (Lavenex, 1999). Through the application of the entry criterion, states in geographical proximity to crisis regions are the first to be deemed responsible and risk being overburdened. Through the application of the family criterion, the Dublin Convention increases the burden on states who already host large communities of migrants. In fact, the Dublin mechanism does 
not provide member States any more protection against inequitable distribution. If anything, it increases their powerlessness vis-à-vis protection seekers. Hailbronner (2000) rightly concludes that the Schengen and Dublin Conventions have established a special type of burden shifting rather than burden sharing.

After more than a decade of cooperation, it is impossible to attest that a shift from costly and inefficient asylum policies (both at the national and at the collective levels) to a coordinated and satisfactory collective action has occurred. The question is therefore to understand why. We propose to build upon Genschel and Plumper's analytical framework to explain the failure of cooperation. The authors use two case studies on international market regulation to identify the conditions under which cooperation is likely to succeed or fail in the shadow of regulatory competition. Multilateral standards regarding the Banking capital requirement in the Bank for International Settlements case is compared with the failure of cooperation in the attempts to harmonise interests tax across EC member states. Genschel and Plumper consider that both issues dealt with a collective action problem. Cooperation benefits were first constrained by the risk of being undercut by competing states. Secondly, the states disagreed about how to deal with the collective action problem. The heterogeneousness of national interests and practices gave rise to conflicts and deadlock. The authors stress the fact that the intersection of collective action problems and problems of interest heterogeneousness is problematic in itself as both problems call for solution strategies that are partly contradictory. In order to solve a problem of collective action, it is useful to extend the range of cooperation so that fewer and fewer actors can potentially free ride. On the contrary, to solve problems of interest heterogeneousness, it is useful to limit the range of cooperators. Heterogeneousness can be contained through the exclusion of dissenters. They conclude that the best combination is achieved by a viable balance between inclusiveness and exclusiveness. 


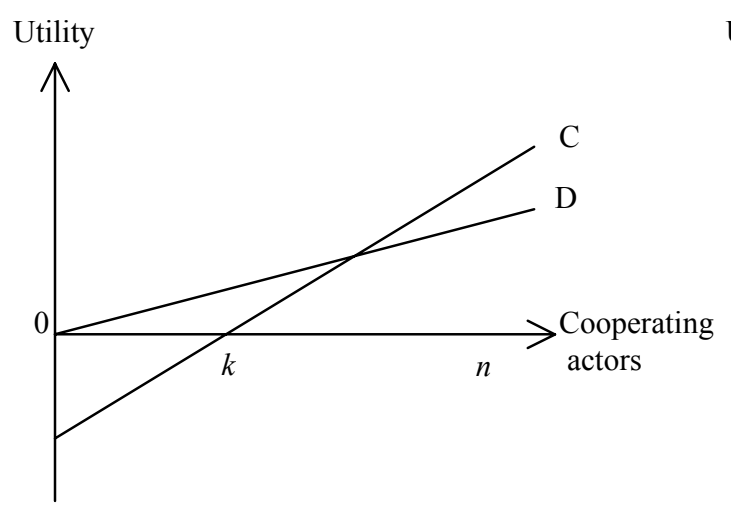

Figure $2 \mathrm{a}$

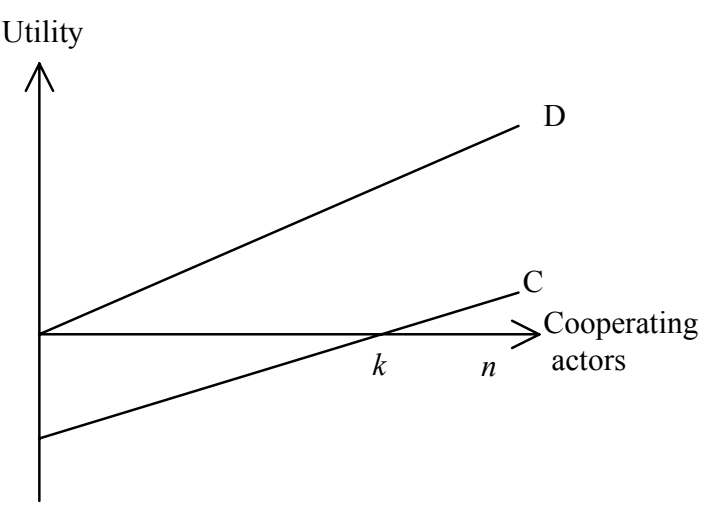

Figure $2 b$

Given a certain level of interest heterogeneity, the feasibility of cooperation depends on two factors : the size of the smallest possible coalition that can gain from cooperation and the external effects of cooperation on non-cooperators. The general idea is that cooperation is relatively difficult to realise if the minimum sized coalition is fairly large and if cooperation makes non-cooperation more attractive to outsiders. Different situations are possible as described in a Schelling diagram (Schelling, 1978). The figures 2a and $2 \mathrm{~b}$ represent multiactors games that indicates how the utility payoff of a given actor varies as a function of his own behaviour and the behaviour of other actors. The range of behavioural alternatives is restricted to the binary choice between cooperation and defection. The behaviour of other actors is marked on the horizontal axis : at point 0 , no other actors cooperates; at point $n$, the whole population cooperates. The $\mathrm{C}$ and $\mathrm{D}$ curves indicate the utility payoff of cooperation and defection for an individual actor. In both figures, the $\mathrm{C}$ and $\mathrm{D}$ curves are upward sloping which means that in either case the utility from cooperation and defection increases as the number of cooperators increases. Hence, all states prefer all other states to cooperate but each state individually prefers to defect as the $\mathrm{D}$ curve is above the $\mathrm{C}$ curve. Non cooperation is the dominant strategy, and non cooperation is the collective equilibrium outcome as predict in the regulatory competition game.

However, there is an important difference between the two cases because the position of point $k$ justifies why actors found it easier to initiate cooperation in the case $2 \mathrm{a}$ than in the case $2 \mathrm{~b} . k$ indicates the threshold for spontaneous cooperation. If there are at least $k$ cooperators, each of them will be at least as well off as in the state of non-cooperation. That $k$ is small in figure 2 a means that it takes only a fairly small number of states to put together the mnimum-sized coalition that can gain from cooperation all by itself. States in favour of cooperation can go ahead without soliciting outside support. The likelihood that cooperation 
is prevented by interest heterogeneity is correspondingly low. Conversely, that $k$ is large in figure $2 \mathrm{~b}$ implies that the emergence of cooperation is less likely. Moreover, the different slopes of the $\mathrm{C}$ and $\mathrm{D}$ curves illustrate why cooperation was not always self-stimulating. In figure $2 \mathrm{a}$, the $\mathrm{C}$ curve is steeper than the $\mathrm{D}$ curve, implying that the gains from cooperation grow faster than the gains from defection as the number of cooperators increases. Every state switching from defection to cooperation reduces the advantage of remaining defectors. Hence, it takes less and less side-payments or coercicion to convince the remaining outsiders to join the club. Eventually, as the C curve crosses the D curve, the outsiders join voluntarily. To the right of this intersection, cooperation is the dominant strategy and the Prisoners' Dilemma mutates into an Harmony game. This is in sharp contrast to the case in figure $2 \mathrm{~b}$ where the $\mathrm{C}$ and $\mathrm{D}$ curve are diverging. The gains from defection are rising faster than the gains from cooperation as the number of cooperators increases. Cooperation is self-limiting and even if enough states agree to constitute a $k$-group, the odds are that the cooperation will not spread to very many other states.

Obstacles to cooperation encountered in the field of asylum can be explained by this approach described in the figure $2 \mathrm{~b}$. There is a problem of collective action insofar as cooperation benefits are "endangered" by the remainder of competition opportunities. Indeed, member states have incentives to organise burden sharing schemes that flow from their belonging to the European Union. Precisely because they are member states, they progressively lose possibilities to insulate themselves against inflows of asylum seekers entering their territory, because of the progressive loss of competence with regard to border controls. At the same time, they are losing capacity to compete because each time a common norm is enacted another part of asylum law is pacified, removed from the ambit of interstate competition (Noll, 2000). In other words, unilateral actions and competing strategies become more and more costly as they have an impact on other fields of European integration (Barbou des Places, 2002a). Yet member states remain sovereign and have not transferred all competence to the EC. To a certain extent, they retain the capacity to insulate themselves. In the absence of a harmonisation process, they may compete with their neighbours by maintaining different degrees of of legal protection. Lower asylum seekers receivers generally countries offering the lowest level of protection - might be dissuaded from participating in cooperation by the belief that unilateral action is less costly than mandatory burden sharing schemes. The British position brings to the fore this possibility. Late signatory of the Dublin Convention, opponent to the German burden sharing project, non-participant in 
the Schengen mechanism, the UK remains firmly convinced that it gains more benefits through unilateral action and therefore constantly avoids cooperation. Transposing Genschel and Plumper's findings here, one may argue that to solve the collective action problem, there exists a need to extend the range of cooperators. In that vein, the extension of the Dublin Convention to non-EC member states like Norway and Switzerland might have a positive impact.

But on the other hand, the characteristic trait of European asylum policies is their heterogeneousness : the problem of the heterogeneousness of interests, values and norms is great indeed. We must stress here the major dissimilarities among asylum policies. To be sure, up until now, we have focused on convergent legislation amendments. But there remain important differences among legislation. For instance, while nearly all the EU member states use accelerated procedures in case of manifestly unfounded application for persons coming from a safe third country, the definition of what is a safe country varies considerably. For some states, the criterion of definition is the asylum rate of recognition, for others, the signature of the Geneva Convention is sufficient evidence, and yet for another group, proof must be given of the absence of political persecution. Examination of recognition quotas also reveals huge differences among member states, whether it be in overall quotas or in decisions concerning refugees from the same country of origin (Rotte, Vogler and Zimmermann, 1996). Regular asylum procedures are also unequal. EU member states differ in the number of judicial proceedings, social benefits granted to protected people, the accommodation of refugees, work permit etc. Lastly, humanitarian statuses have nothing in common, nor do return and repatriation policies.

This heterogeneousness in legislation and policy translates the interest heterogeneousness as the use of joint product model has shown. As benefits of asylum protection differ among member states, they have different interest in cooperation. Therefore this interest heterogeneity might be resolved by limiting the range of cooperators. But, as spontaneous cooperation cannot easily emerge, it appears that European countries favour recently the way of centralised action to organise cooperation.

\subsection{Need for centralised action : post-Amsterdam evolution}

The decision of 1997 to sign the Treaty of Amsterdam reveals the member states' intention to establish real and sustainable cooperation in the field of asylum. The Treaty of Amsterdam 
might be the turning point of the " new approach" insofar as states have transferred important competences to the Community level on several matters concerning asylum and refugee law. From a prospective point of view, the current legal developments on the basis of the Amsterdam provisions can be interpreted as clues of a new tendency, whereby member states try to set out a soft but centralised cooperation aiming at replacing or framing the previous regulatory competition. Indeed, the cooperation instruments developed today differ from the cooperative attempts of the 90s. They promote an institutionalised and centralised cooperation in the field of asylum.

The 90s cooperative schemes have showed that cooperation can be efficient only if it tries at the same time to tackle the causes of regulatory competition and to organise centralised burden sharing. On the first point, an evolution is already perceptible. In the line of the 3 December 1998 Action Plan (Action Plan of the Council and the Commission on how best to implement the provisions of the Treaty of Amsterdam on an area of Freedom, Security and Justice, OJ C19, 23.01.1999), the European institutions have enacted or proposed important norms that all lay down minimum standards. They deal with reception of the applicants for asylum in the members states, with the asylum procedures, with the qualification and status of refugees and with temporary protection granted to displaced persons. These norms all purport to approximate the national legislation and therefore to suppress or reduce the fuel of the asylum shopping strategy. The explanatory memorandum of the proposed directives constantly recalls that "any differences solely connected with family, cultural or historical factors, likely to influence in one way or another the flows of asylum applicants, should as far as possible disappear between the member states where such movements is purely caused by differences in legal framework". Harmonisation corresponds thus to a first step of cooperation, that Noll calls "norm sharing" (Noll, 2000). In addition, by accepting harmonisation and laying down minimum standards, member states agree on a limitation to their competitive and strategic de-regulation. By approximating their legislation and recognising equivalent rights to asylum seekers, they pacify the harmonised areas from the ambit of regulatory competition. Certainly, regulatory competition is still plausible insofar as harmonisation remains limited. The level of the standards adopted remains also crucial, because minimum standards might turn out to be minimal standards as the result of a difficult political negotiation at the Council and possible compromise on the lowest common denominator. But another analysis (Reich, 1992) considers that minimum provisions or standards can facilitate the emergence of better rules. Indeed, minimum standards allow 
choice between legal orders and experimentation among different solutions. In other words, competition between legal orders could be encouraged by the European institutions only if it does not fall below a certain level. The current harmonisation process could correspond to this description and the minimum standards to be adopted before 2004 might constitute a nonregression clause preventing member states from lowering their existing standards.

The European cooperation on asylum differs from the 90's system for a second reason. It aims at establishing centralised burden sharing. In the frame of the Freedom, Security and Justice Area Development, the Council has received competence to enact measures promoting a balance of efforts between member states in receiving refugees and displaced persons. To be true, there is no time limit for the adoption of these measures, which is a flaw of the system. But since 2000, two important norms have been enacted. The first one is the creation of a European Refugee Fund (Decision 2000/56 of September $18^{\text {th }}$ 2000, OJ 6.10.2000) and the second if the Directive of 20 July 2001 on minimum standards for giving temporary protection in the event of mass influx of displaced persons and on minimum measures promoting a balance of efforts between members states in receiving such persons (Directive 2001/55, OJ 7.8.2001). Pursuant to the Temporary protection Directive, a decision of the Council shall establish that there is a situation of mass influx of displaced persons and this decision shall have the effect of introducing temporary protection for the persons seeking protection. Once the solidarity scheme is established, the member states indicate their reception capacity, i.e. the number of protection seekers they wish to welcome. The Council can recommend additional support for member states particularly affected. Although this mechanism has never been used, it represents a first and major step in the cooperation for people-sharing. The European Refugee Fund Decision is based on a different but complementary logic. It favours a fiscal burden sharing system by creating mechanisms of financial compensation to burdened states. The Fund will finance actions relating to conditions for reception, integration of the persons in the host society and repatriation. Progressively, the subsidies will be allocated to the state bearing the major costs of hosting protection seekers. Despite its limited budget, the Fund represents a substantive change insofar as states have agreed on setting institutional financial solidarity.

On many aspects, the current European asylum policy is unlikely to put an end to the member states individual actions. It may also favour cooperation organising burden shifting towards non-European countries (Barbou des Places, 2002a). But it represents a significant attempt to deal collectively and comprehensively with the asylum dilemma by acting on the 
causes of regulatory competition (minimum standards), and by promoting complementary measures of centralised burden sharing, both for people sharing and fiscal burden sharing.

Finally, a new trend is the institutionalisation of information exchange. First, the Council is a major forum of debates and bargaining. Second, the Commission permanently compares the national legal systems and practices in order to identify and import at the European level the "national best practices". In addition, the commission has recently enacted a communication that promotes the use of the "Open Method of Coordination" in the field of migration and asylum (COM (2000) final). If put into practice, the open method of coordination will efficiently complement the legislative works. The Commission will indeed stimulate open and public debate on the national asylum policies and oblige states to justify their individual actions. The commission relies on the "shame" leverage to dissuade states from implementing externalising measures that would shift the asylum burden to the other member states.

Thus, despite its important limitations, the current setting of a European asylum policy demonstrates the states' will to cooperate. Regulatory competition is unlikely to disappear but is progressively framed by the action of the European institutions and tends to be absorbed by a political competition for best norms inside the European political debate.

\section{Bibliography}

Acharya, A. and Dewitt, D. (1997), Fiscal Burden-Sharing, in Hathaway, C. (ed.), Reconceiving International Refugee Law, Nijhoff, 1997, p. 111.

Achermann, A. and Gattiker, M. (1995), Safe Third Countries: European Developments, International Journal of Refugee Law, Vol. 7, No. 1, p. 19.

Barbou des Places, S (2002a), Burden Sharing in the field of Asylum. Legal motivations and Implications of a Regional Approach, Paper presented for the $3^{\text {rd }}$ Workshop of the UACES Study Group on EU Burden-Sharing 'Internal and External Dimensions of EU BurdenSharing, 26-27 April 2002, London School of Economics, fothcoming Working Paper, RSC, European University Institute, Florence, on file with the authors.

Barbou des Places, S. (2002b), Evolution of Asylum Legislation in the Field of Asylum. Insights from regulatory Competition Theory, forthcoming Working Paper, LAW, European University Institute, on file with the authors.

Barnard, C. (2000) Social dumping and the race to the bottom: some lessons from the European Union from Delaware?, 25 European Law Review.

Bocker, A and Havinga, T (1998), Asylum migration to the European Union : Patterns of origin and destination, Institute for the Sociology of law, Nijmegen, published by the Office for Official Publication of the European Communities. 
Bouteiller-Paquet, D. (2001), L'Europe et le droit d'asile, L'Harmattan.

Chatelard, G. (2002), In transit: Iraqi forced migrants in Jordan. Conditions, religious networks and smuggling rings, Working Paper, RSCAS, IUE, Florence, forthcoming

Crepeau François (1995), Droit d'asile, de l'hospitalité aux contrôles migratoires, Collection de Droit international, Bruylant.

Cruz, A. (1995) Shifting responsibility, Carrier's liability in the member states of the European Union and North America, Trentham Book.

Deakin, S. (2000), Regulatory competition versus harmonisation in European Company law, Working Paper No. 163, ESRC, Centre for Business research, University of Cambridge.

Deffains, B. (2001), Competition between legal systems, a comparative law and economics perspective, in Law and Economics in civil law countries, JAI Press (Deffains and Kirat eds).

European Council on refuges and Exiles (1995), Safe third countries : Myths and realities, London, available on www.ecre.org

European Council on Refugees and Exiles (2001), The promise of protection: Progress towards a European Asylum Policy since Tampere, available on www.ecre.org

Genschel P. and Plumper T. (1997), Regulatory Competition and International Cooperation, MPlfG Working Paper 97/4.

Ghosh, B. (1998), Huddled Masses and UncertainShores : Insights into irregular Migration, International Organization for Migration, Martinus Nijhoff, The Hague

Guiraudon, V. (2000), European Integration and Migration Policy : Vertical Policy-making as Venue Shopping, Journal of Common Market Studies, June, Vol. 38, No. 2.

Hailbronner, K. (2000), Immigration and Asylum Law and Policy of the European Union, Kluwer.

Harvey, C.J. (1998), The European Regulation of Asylum: Constructing a Model of Regional Solidarity, European Public Law, Vol. 4, Issue 4, p. 561

Hans S. and Suhrke, A., (1997) Responsability Sharing, in Hathaway, C. (ed.), Reconceiving International Refugee Law, Nijhoff, 1997, p. 83.

Jeannin, L., Meneghini, M., Pauti, C., Poupet, R., (1999), Le droit d'asile en Europe. Etude comparée, L'Harmattan.

Joly, D. (1999), A new asylum regime in Europe, in Nicholson, F. and Twomey, P. (eds), Refugee, Rights and realities. Evolving international concepts and regimes, Cambridge University Press, p. 336,

Landgren, K. (1999), Deflecting international protection by treaty: bilateral and multilateral accords on extradition, readmission and the inadmissibility of asylum request, UNHCR's New Issues in Refugee research, Working Paper No. 10, available on www.unhcr.ch

Lavenex, S. (1999), Safe Third Countries, Extending the EU Asylum and Immigration Policies to Central and Eastern Europe, Central and European University Press.

Milner J. (2000), Sharing the Security Burden : Towards the Convergence of Refugee Protection and State Security, QEH Working Paper.

Noll, G. (1997), 'The Non-Admission and Return of Protection Seekers in Germany', International Journal of Refugee Law, Vol. 9, No. 3, p. 415 
Noll, G. (1998), Prisoners' Dilemma in Fortress Europe: On the Prospects for Equitable Burden-Sharing in the European Union, German Yearbook of International Law, Vol. 40, p. 405.

Noll, G. (2000), Negotiating Asylum, The EU acquis, Extraterritorial Protection and the Common Market of Deflection, Nijhoff.

Olson M. and Zeckhauser R. (1966), An Economic Theory of Alliances, Review of Economics and Statistics, 48, p. 266-279.

Reich N. (1992),

Rotte, R., Vogler, M., Zimmermann, K.F., (1996), Asylum migration and Policy coordination in Europe, Dicussion Papers, Munchener Wirtschaftswissenschaftliche Beitrage, 96-11, Juli 1996.

Salt, J. and Hogarth, J. (2000), Migrant Trafficking and Human Smuggling in Europe : A review of the Evidence with case-studies from Hungary, Poland and Ukraine, International Organization for Migration, Geneva.

Sandler T. and Hartley K. (2001), Economics of Alliances : the Lessons for Collective Action, Journal of Economic Literature, 39, p. 869-896.

Schelling T. (1978), Micromotives and Macrobehavior, Norton, New York.

Sudgen R. (1982), On the Economics of Philanthropy, Economic Journal, 92, p. 341-350.

Suhrke, A., (1998), Burden-sharing during Refugee Emergencies: The logic of Collective versus National Action, Journal of Refugee Studies, Vol. 11, No. 4, p. 396.

Thielemann, E., Between Interests and Norms: Explaining Burden-Sharing in the European Union, paper presented for the UACES workshop on European Burden-Sharing and Forced Migration, London School of Economics, 12 January, 2002, on file with the author.

Thouez, C. (2000), Towards a common European migration and asylum policy?, UNHCR's New Issues in Refugee research, Working Paper No. 27, available in unhcr.ch

Tiebout, (1956) A pure theory of local expenditure, Journal of Political Economy, 1956, p. 416

UNHCR, (1997), The state of the world's refugees, 1997-98, A Humanitarian Agenda, Oxford University Press.

UNHCR, (1999), Refugees and Others of concerns to UNHCR, Statistical overview, United Nations High Commissioner for Refugees, Geneva, July 2000, available on http://www.unher.ch

Vink, M. (2001), The limited Europeanization of Domestic Asylum Policy: EU Governments and Two-Level Games, Paper presented at the first YEN Research Meeting on Europeanisation, Workshop IV 'Europeanisation of Domestic Policies', 2-3 November 2001, Siena, on file with the author.

Vink, M. and Meijerink, F., (2002), Asylum Politics in the European Union : testing the 'Implicit Burden-Sharing Thesis', Paper presented for the $3^{\text {rd }}$ Workshop of the UACES Study Group on EU Burden-Sharing 'Internal and External Dimensions of EU Burden-Sharing, 2627 April 2002, London School of Economics, paper on file with the authors. 